OPEN ACCESS

Edited by:

Felix Ng,

University of Sheffield

United Kingdom

Reviewed by:

Mark Skidmore,

Montana State University,

United States

Alan Rempel,

University of Oregon, United States

Denis Samyn

Royal Museum for Central Africa,

Belgium

*Correspondence:

Christophe Thomazo

Christophe.thomazo@u-bourgogne.fr

Specialty section:

This article was submitted to

Cryospheric Sciences,

a section of the journal

Frontiers in Earth Science

Received: 13 February 2017

Accepted: 22 August 2017

Published: 21 September 2017

Citation:

Thomazo C, Buoncristiani J-F, Vennin E, Pellenard P, Cocquerez T,

Mugnier JL and Gérard E (2017) Geochemical Processes Leading to

the Precipitation of Subglacial

Carbonate Crusts at Bossons Glacier,

Mont Blanc Massif (French Alps).

Front. Earth Sci. 5:70

doi: 10.3389/feart.2017.00070

\section{Geochemical Processes Leading to the Precipitation of Subglacial Carbonate Crusts at Bossons Glacier, Mont Blanc Massif (French Alps)}

\author{
Christophe Thomazo ${ }^{1 *}$, Jean-Francois Buoncristiani ${ }^{1}$, Emmanuelle Vennin ${ }^{1}$, \\ Pierre Pellenard ${ }^{1}$, Theophile Cocquerez ${ }^{1}$, Jean L. Mugnier ${ }^{2}$ and Emmanuelle Gérard ${ }^{3}$ \\ ${ }^{1}$ Laboratoire Biogéosciences UMR 6282 UBFC, Centre National De La Recherche Scientifique, Université Bourgogne \\ Franche-Comté, Dijon, France, ${ }^{2}$ Centre National De La Recherche Scientifique, Université de Savoie-Mont-Blanc, Chambéry, \\ France, ${ }^{3}$ Institut de Physique du Globe de Paris, Sorbonne Paris Cité, Université Paris Diderot, Centre National De La \\ Recherche Scientifique UMR 7154, Paris, France
}

Cold climate carbonates can be used as paleoclimatic proxies. The mineralogy and isotopic composition of subglacially precipitated carbonate crusts (SPCCs) provide insights into the subglacial conditions and processes occurring at the meltwaterbasement rock interface of glaciers. This study documents such crusts discovered on the lee side of a gneissic roche moutonnée at the terminus of the Bossons glacier in the Mont Blanc Massif area (France). The geological context and mineralogical investigations suggest that the Ca used for the precipitation of large crystals of radial fibrous sparite observed in these crusts originated from subglacial chemical weathering of Ca-bearing minerals of the local bedrock (plagioclase and amphibole). Measurements of the carbon and oxygen isotope compositions in the crusts indicate precipitation at, or near to, equilibrium with the basal meltwater under open system conditions during refreezing processes. The homogeneous and low carbonate $\delta^{13} \mathrm{C}$ values (ca. $-11.3 \%$ ) imply a large contribution of soil organic carbon to the Bossons subglacial meltwater carbon reservoir at the time of deposition. In addition, organic remains trapped within the SPCCs give an age of deposition around 6,500 years cal BP suggesting that the Mid-Holocene climatic and pedological optima are archived in the Bossons glacier carbonate crusts.

\footnotetext{
Keywords: glacier, paleoclimate, Mont Blanc, subglacially precipitated carbonate crusts, stable isotope, Holocene climatic optimum
}

\section{INTRODUCTION}

In cold climatic regions, carbonate precipitates are commonly observed features at rock/ice interfaces wherever there is or was flowing or standing water. These cold-climate carbonates, namely cryogenic carbonates, are found on the surface of aufeis along riverbeds, in dry lakebeds, on the upper surface of clasts and bedrock, in fissures in bedrock outcrops, on the underside of clasts in soil profiles, in sand dunes, and in caves, either as cryogenic calcite or speleothems (see Lacelle, 2007 and references therein). The geochemical signature $\left(\delta^{18} \mathrm{O}\right.$ and $\left.\delta^{13} \mathrm{C}\right)$ of these carbonate deposits can potentially be used as paleoclimatic and paleoenvironmental proxies (e.g., Clark et al., 2004), although diverse precipitation mechanisms have been suggested to explain their origin. Processes including freezing (Hallet, 1976; Killawee et al., 1998), changes in the partial pressure 
of $\mathrm{CO}_{2}$ (Fairchild et al., 1994), and alkalinity (Marlin et al., 1993), desiccation, and intensive evaporation of calcium bicarbonate solution (Bunting and Christensen, 1978; Lacelle, 2007) could cause cryogenic carbonate precipitation. Because these processes tend to fractionate the carbon and oxygen isotopes in most cases, paleoclimatic and paleoenvironmental reconstructions should not be performed using these records, unless one can demonstrate precipitation at isotopic equilibrium with the parent fluids or reconstruct the initial signals by accounting for the degree of fractionation. Besides these abiotic processes, some cryogenic calcite precipitates show biological signatures suggesting that microbially mediated precipitation may also occur (Swett, 1974; Clark et al., 2004; Parnell et al., 2006).

Among cryogenic carbonates, subglacially precipitated carbonate crusts (SPCCs) represent a unique archive of subglacial hydrologic conditions at the ice-bed interface and may trace the isotopic composition of the basal ice and meltwater at the time when the crusts formed. SPCCs usually occur in the form of thin calcite centimeter thick coatings at the surface of bedrock exposed by receding temperate modern glaciers. The subglacial nature of these crusts is inferred from the fact that: (i) they are restricted to the lee side of clasts (Lacelle, 2007), (ii) they show a fluted surface parallel to the direction of ice flow ( $\mathrm{Ng}$ and Hallet, 2002), (iii) they are commonly laminated with dark and light color bands and are composed of micritic or fibrously sparitic calcite crystals (Lacelle, 2007).

SPCCs are commonly observed on carbonate bedrock and have been described in the French Alps (Hallet, 1976; Souchez and Lemmens, 1985; Sharp et al., 1990; Fairchild et al., 1993; Hubbard and Hubbard, 1998), in the Rockies (Ford et al., 1970; Hanshaw and Hallet, 1978; Ng and Hallet, 2002), and on bedrock in the Ottawa-Valley region that was covered by the Laurentide Ice Sheet during the Late Pleistocene (HillaireMarcel et al., 1979). The most common genetic model assumed that SPCCs form as meltwater becomes supersaturated with $\mathrm{CaCO}_{3}$ during the regelation process, when basal meltwater generated by pressure-induced melting of ice on the upstream side of glacier bed undulations dissolves $\mathrm{CaCO}_{3}$ from the bedrock. As this film of water refreezes on the lee side of the subglacial relief, solutes are concentrated in the residual water, and upon saturation, $\mathrm{CaCO}_{3}$ precipitates (Hallet, 1976; Hanshaw and Hallet, 1978; Souchez and Lemmens, 1985). If refreezing is incomplete, $\mathrm{CaCO}_{3}$ precipitation may occur from residual meltwater transported from elsewhere in the subglacial system (Hallet, 1976). Accordingly, the majority of these SPCCs are limited to glaciers flowing on limestone terrains.

However, SPCCs have also been documented on igneous and metamorphic bedrocks in three geographical locations away from sedimentary carbonate sources with surface and ground waters far from equilibrium with respect to calcite. These corresponding types of cryogenic carbonates have been described in the Vestfold Hills of Antarctica (Aharon, 1988), the Chinese Tien Shan Mountains (Liu et al., 2005), and the Barnes Ice Cap on central Baffin Island, in the eastern Canadian Arctic (Refsnider et al., 2014). For the first and third locations listed here, the respective authors reported carbon and oxygen isotopic signal of SPCCs. Vestfold Hills aragonitic SPCCs are highly depleted in ${ }^{18} \mathrm{O}$ and slightly depleted in ${ }^{13} \mathrm{C}$ relative to the VSMOW and VPDB standards, respectively $\left(\delta^{18} \mathrm{O}=-15.7 \pm 0.9 \% ; \delta^{13} \mathrm{C}=-3.6 \pm 0.4 \%\right.$ ). Barnes Ice Cap SPCCs show a mean $\delta^{18} \mathrm{O}$ value of $6.6 \pm 0.8 \%$ VSMOW and ${ }^{13} \mathrm{C}$ values between -11 and $-7 \%$ VPDB. These isotopic signals have been related to subglacial carbonate precipitation reflecting kinetic processes (Aharon, 1988) or quasi-isotopic equilibrium with parent water under open system conditions (Refsnider et al., 2014). Refsnider et al. (2014) also showed that the Barnes Ice Cap subglacial calcite crusts have a typical fabric (i.e., columnar, with sparite predominating over micrite) that supports near-equilibrium fractionation, and they suggested that the carbon incorporated in the SPCCs was predominantly derived from old soil carbon sources. Nearequilibrium fractionation is also deduced from SPCCs located in limestone bedrock areas in Holocene and Pleistocene examples (Lacelle, 2007) suggesting that the $\mathrm{C}-\mathrm{O}$ isotopic signals of the SPCCs might be useful proxies for paleoclimatic (e.g., air temperature) and paleoenvironmental (e.g., carbon cycle) conditions.

In this study, we describe new-found SPCCs on a gneissic roche moutonnée of the Bossons glacier bedrock and report the stable isotope ratios for carbon and oxygen together with radiocarbon dating of organic remains. For the first time, we perform detailed isotopic measurements on the finely laminated layers of SPCCs and demonstrate that calcium carbonate (calcite) saturation during refreezing does not result from closed system Rayleigh distillation but rather precipitation at, or close to, equilibrium fractionation. We provide new insights into the genetic mechanisms of SPCCs associated with glaciers and the paleoenvironmental conditions in the Bossons glacier area during the Holocene.

\section{GEOLOGICAL SETTING}

The cryocarbonates investigated here come from the terminus of the Bossons glacier, in the Mont Blanc glacier system in the French Alps (Figure 1). The Mont Blanc Massif records the Variscan-Alpine poly-orogenic evolution of the Western Alps (von Raumer et al., 2003) ending with the $\sim 300 \mathrm{Ma}$ large intrusion $\left(\sim 225 \mathrm{~km}^{2}\right)$ of the Mont Blanc granite pluton (Bussy et al., 1989). The external massifs arose during the Late Miocene phase of alpine orogenesis (Mugnier et al., 1989; Cannic et al., 1996; Leloup et al., 2005). The Bossons glacier flows northward down the north face of Mont Blanc from its summit (4,810 $\mathrm{m}$ a.s.l. in elevation), which is comprised of Mont Blanc granite $(303 \mathrm{Ma})$ to the front of the glacier (at $1,450 \mathrm{~m}$ to $1,750 \mathrm{~m}$ a.s.l.) composed of Ordovician orthogneisses. The ice thickness of the Bossons glacier has a mean value of $60 \mathrm{~m}$ and a maximum of $\sim 160 \mathrm{~m}$ (Huss and Farinotti, 2012; Godon et al., 2013). The Bossons glacier is inferred to be polythermal. Measurements taken in 2005 from a borehole at an altitude of $4,250 \mathrm{~m}$ indicated a vertical ice temperature profile that decreased from $-7^{\circ} \mathrm{C}$ at the surface to $-11^{\circ} \mathrm{C}$ at $90 \mathrm{~m}$ depth, and hence remain constant down to the frozen base of the glacier (Vincent 


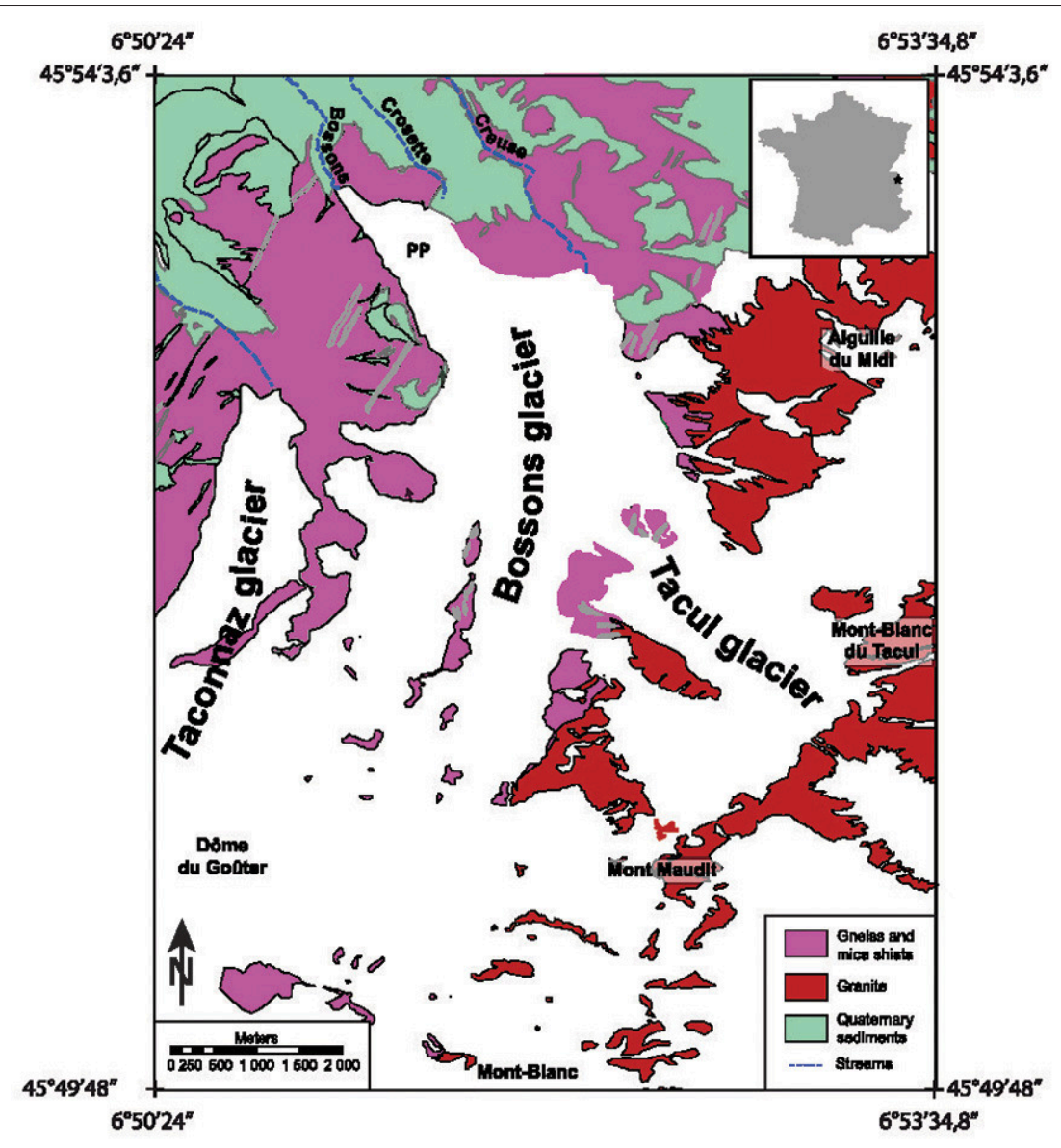

FIGURE 1 | Map showing the Mont Blanc glacier system and simplified bedrock geology around Mont Blanc. The inset shows the location in France. The proglacial Creuse, Crosette and Bossons streams, and Pyramids plateau (PP) are also indicated modified after Guillon et al. (2015).

et al., 2007). The firn temperature is negative at elevations above 3,700 $\mathrm{m}$ (Suter and Hoelzle, 2002) and ice-flow advection moves cold ice down to lower altitudes. The distribution of the basal ice temperature of the Bossons glacier is complex and a minimum elevation of $3,300 \mathrm{~m}$ has been suggested as the boundary between cold and temperate (at the melting point) basal ice (Le Meur and Vincent, 2006). The Bossons glacier is an exceptionally steep glacier with a mean slope of $\sim 28^{\circ}$, which drives ice flows speeds at more than $1 \mathrm{~m}$ /day in the summer (data from an altitude of 2,300 m; Fallourd et al., 2011). The glacier topography is typically disrupted by crevasses and seracs, but a remarkably smooth surface is observed at an altitude of $1,700-1,850 \mathrm{~m}$; this zone is characterized by a flattening of the slope ("Pyramids plateau"). Three outlet streams characterize the subglacial hydrological network beneath the Bossons. The Crosette stream emerges at an altitude of $1,760 \mathrm{~m}$ from the area of the Pyramids plateau (Figure 1). Two other streams, Creuse (outlet at 2,300 m) and Bossons (outlet at 1,450 m) flow into the Arve River. Although the details of the subglacial meltwater network are unknown, Godon et al. (2013) suggested that the highest outlet (Creuse) drains mostly from the Tacul glacier, while the lowest outlet (Bossons) collects subglacial meltwater from a relatively small catchment area of less than $0.5 \mathrm{~km}^{2}$. The bedrock in the catchment of the Bosson glacier consists of calc-alkaline granites (ca. $303 \mathrm{Ma}$ ) and metamorphic gneiss and amphibolite (ca. 330-470 Ma). There is no evidence of the presence of metamorphosed carbonate rocks or fracture filling carbonates.

\section{SAMPLING AND ANALYTICAL METHODS}

Cryocarbonates were sampled close to the Crosette stream outlet on the right side of the Pyramids plateau in 2012 (Figure 2A). Seven cryocarbonate samples (Table 1) were collected using a chisel and hammer on the lee sides of granito-gneissic rochesmoutonées at $\sim 1,760 \mathrm{~m}$ (Figure $2 \mathrm{~B}$ ). Two representative samples of the associated bedrock and a sample of nearby glacial flour were also collected (Table 1). Due to the scarcity and small size of samples collected, we developed the analytical strategy depicted in Table 1.

Photonic and low-resolution scanning electronic microscopy (SEM) observations were performed using a Leica MZ205c and Hitachi TM 1000 (back-scatter electron imaging mode, $15 \mathrm{keV}$ ) at the Biogéosciences Laboratory (Université de 


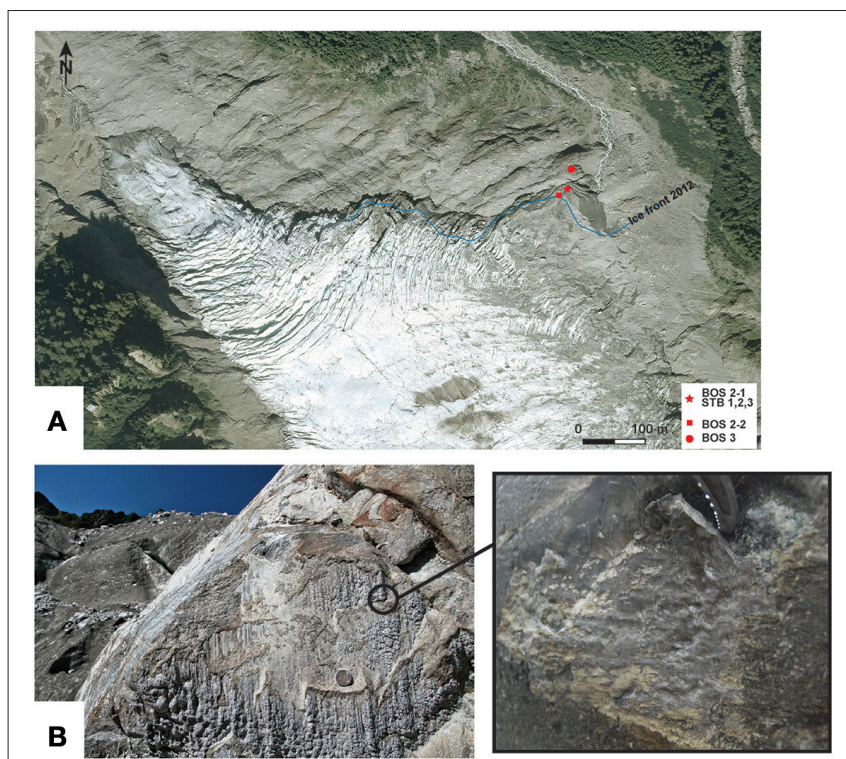

FIGURE 2 | (A) Location of the cryocarbonate samples reported on the 2008 aerial photograph from the IGN ORTHO ${ }^{\circledR} 2.5$ m database. Samples BOS 2-1, STB 1-3, and BOS 2-2 were located under the glacier and sample BOS 3 was in proglacial position in 2008. The blue line marks the 2012 glacier front position. (B) Cryocarbonate samples outcropping on the lee side of the vertical roches-moutonées show a fluted surface parallel to the direction of the ice flow. Right panel zooms into an area to show details.

Bourgogne, Dijon). High-resolution images were taken with a JEOL JSM 6400F Field Emission SEM equipped with an Oxford INCA Energy 300 X-ray Energy Dispersive Spectrometer (EDS) system for all chemical analyses at the ARCEN platform (Laboratory Institut Carnot de Bourgogne in Dijon, Université de Bourgogne, France). Sections of the samples were prepared for SEM analyses and were subsequently coated with $\sim 10 \mathrm{~nm}$ of graphite using a High Resolution Ion Beam Coater, GATAN 681. The high-resolution images were taken in backscattered electron imaging mode to enhance the compositional contrast. EDS measurements of the X-ray fluorescence were made on individual spots. The relative accuracy of the semi-quantitative elemental analysis is higher than 5\%. These facilities were used to identify minerals and examine the calcite morphologies in the samples.

Epifluorescence and confocal laser scanning microscopy observations were carried out at the Institut de Physique du Globe, laboratoire de géomicrobiologie, Paris, France, with an Olympus FluoView1000 confocal microscope and an objective UPSLAPO 40XO NA: 0.90. Fluorescence confocal images were obtained with concomitant excitation at wavelengths of 405,488 , and $543 \mathrm{~nm}$ by collecting the emitted fluorescence between 425-475, 500-530, and 560$660 \mathrm{~nm}$, respectively. The images were acquired, visualized and processed using the F10-ASW FLUOVIEW software (Olympus).

Raman spectroscopic analyses were carried out at the Institut de Physique du Globe, laboratoire de géomicrobiologie, Paris, France, with a Renishaw In Via Raman spectrometer coupled to an Olympus FluoView1000 confocal microscope and a 785 $\mathrm{nm}$ laser source. Epifluorescence images were obtained using an Olympus cube UV bande large U-MWU2 and a 50X Objective. Beam centering and Raman spectra calibration were performed daily on a $\mathrm{Si}-\mathrm{Al}$ microprocessor chip displaying a characteristic Si Raman shift at $520.4 \mathrm{~cm}^{-1}$. Extended mode analysis in the range of $100-4,000 \mathrm{~cm}^{-1}$ was used to acquire spectra. Light was dispersed by a holographic grating with 1,200 grooves/mm and the signal analyzed with a RENCAM charge-coupled device (CCD) detector. Laser intensity set as $1 \%$; the exposure time was $10 \mathrm{~s}$ for each spectrum. All of these operations were performed with Renishaw software Wire 2.0.

Aliquots of the bulk rock samples were powdered to $<60 \mu \mathrm{m}$ using a ring and puck mill at the Biogéosciences Laboratory of the Université de Bourgogne in Dijon.

$\mathrm{X}$-ray diffraction (XRD) was performed on both the bulk cryocarbonate and bedrock powders using a Bruker AXS D4 Endeavor diffractometer with $\mathrm{CuK}_{\alpha}$ radiations, a LynxEye detector and $\mathrm{Ni}$ filter, with a voltage of $40 \mathrm{kV}$ and an intensity of $25 \mathrm{~mA}$ at the Biogéosciences Laboratory (Université de Bourgogne in Dijon, France). The goniometer performed a scan from $2.5^{\circ}$ to $65^{\circ} 2 \theta$ for each run. The identification and semiquantitative estimates of the minerals were made according to the position and area of the mean basal reflections.

Three samples (STB-1, STB-3, and BOS2-1B) were pretreated by acidification $(\mathrm{HCl})$ and analyzed for their total organic ${ }^{14} \mathrm{C} /{ }^{12} \mathrm{C}$ and ${ }^{13} \mathrm{C} /{ }^{12} \mathrm{C}$ ratios using an accelerator mass spectrometry (AMS; Beta Analytic inc, Miami, FL, USA; http:// www.radiocarbon.com) in order to determine the age of the organic remains. Only STB-1 yielded enough organic material for this determination; its age is reported relative to cal BP using Libby's ${ }^{14} \mathrm{C}$ half-life (5,568 years) and the total organic carbon isotopic composition is reported using the standard $\delta$-notation in permil (\%o) relative to VPDB. The reproducibility is reported as a $1 \sigma$ standard deviation.

Carbonate carbon and oxygen isotope analyses (i.e. $\delta^{13} \mathrm{C}_{\text {carb }}$ and $\left.\delta^{18} \mathrm{O}_{\text {carb }}\right)$ were carried out at the Biogéosciences Laboratory (Université de Bourgogne in Dijon, France). The isotopic ratios were measured on bulk rocks and through microsampling of cryocarbonates laminations using a Dremel ${ }^{\circledR}$ driller (Table 1). Ninety to $300 \mu \mathrm{g}$ of powder produced during the drilling process was collected and then loaded into glass vial with septum for isotopic analyses. The vials were flushed via an autosampler with $\mathrm{He}$ and evacuated in order to remove atmospheric gases. Each sample was then reacted with $500 \mu$ of $100 \%$ phosphoric acid at $90^{\circ} \mathrm{C}$ for $17 \mathrm{~min}$ using an online carbonate preparation line coupled to an IsoPrime stable isotope ratio mass spectrometer (Isoprime, Manchester, UK). The inorganic carbonate content was checked manometrically from the $\mathrm{CO}_{2}$ yield; all isotopic values are reported in the standard $\delta$-notation in permil (\%o) relative to VPDB and VSMOW, respectively, by assigning a $\delta^{13} \mathrm{C}$ value of $+1.95 \%$ and a $\delta^{18} \mathrm{O}$ value of $+28.65 \%$ o to the NBS19 international standard. The long-term reproducibility of the NBS19 replicate analyses (3 months) is better than \pm $0.09 \%$ o $(1 \sigma)$ and $\pm 0.12 \%$ o $(1 \sigma)$ for the carbon and oxygen isotopes, respectively. $\mathrm{H}_{3} \mathrm{PO}_{4}$ blank tests were performed and the 


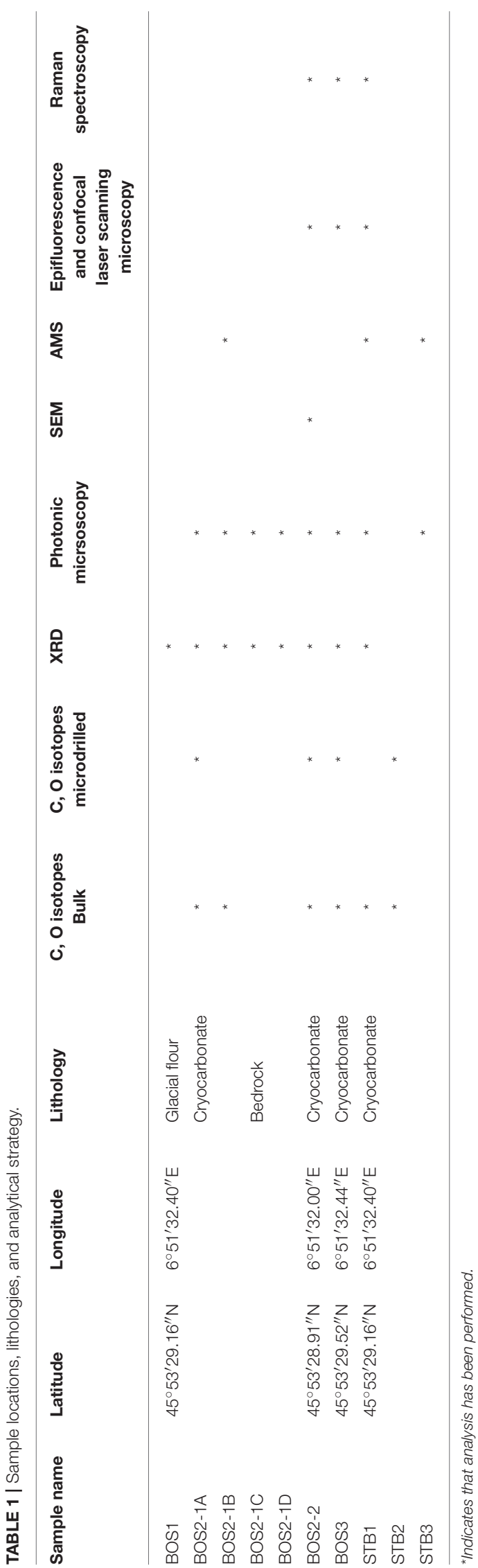

evolved $\mathrm{CO}_{2}$ was below the detection limit of the online-IRMS system.

\section{RESULTS}

The cryocarbonate samples are in the form of carbonate crusts ranging from $5 \mathrm{~mm}$ up to $1 \mathrm{~cm}$ thick, and several decimeters wide (Figures 2B, 3). They developed on the lee sides of roche moutonnée surface features and become exposed due to the recent retreat of the Bossons glacier. In 2008, they were located beneath the glacier, according to the aerial orthophoto (BD ORTHO $^{\circledR}$ (RGE) from the Institut Geographique National, Figure 2A).

\section{Sedimentary Structure and Texture}

The macrostructures of the cryocarbonate samples (Figure 3) show parallel and concentric laminae, with alternating lightcolored and dark-colored bands suggesting rhythmic lamination. Detailed examination showed that these laminae consist of several micrometer-thick dark micritic laminae inter-layered with acicular and elongated radial fibrous cement (Neuser and Richter, 2007) that are locally dissolved, forming unconformable contacts (Figures 4A,B). The carbonate crusts lie on fine-grained (silt-size) material resulting from glacial erosion and weathering of the basement rock. The morphology of the laminae is influenced by that of the bedrock.

The samples BOS2-1B and BOS3 show remarkable planar beddings that extend laterally without morphological changes, and BOS2-1A and STB3 show oblique-to-vertical pressuredissolution features (i.e., dissolution structures) probably inherited from the subglacial water pressure and ice load (Figure 3). A discrete botryoid to coalescent fabric is observed on samples BOS2-1A, BOS2-1B, BOS3, and STB3 (Figures 4A-C,E).

The petrographic observations of samples STB3, BOS2$1 \mathrm{~A}, \mathrm{BOS} 2-1 \mathrm{~B}$, and BOS3 show that their formation involved multiple phases of precipitation (Figures $4 \mathrm{~A}-\mathrm{F}$ ). The $\mathrm{cm}$-thick layers are composed of an alternance of 50-150 $\mu \mathrm{m}$ lightcolored microsparite and 10-50 $\mu \mathrm{m}$ dark-colored micrite rich in impurities bands (Figures 4B,F). The growth initiation of the cement layers is largely controlled by the underlying substrate morphology. Botryoid and coalescent fabrics underline the initial growing phases (Figures 3, 4A-C,E). At the boundary between the layers, dissolution is observed affecting the fibrous calcite crystals (Figures 4A-D) and producing porosity that is either infilled by cements (STB3) or clastic sediments (Figures 4D,G,H) or is empty (BOS2-2 and STB1). Some layers are truncated by an erosional event and separated by an unconformable contact from a new layer (Figures 4B,D). This observation suggests episodes of dissolution and discontinuous precipitation. Within individual layers, slight dissolution may also occur during a continuous depositional cycle (Figures 4E,F; Liu et al., 2005).

The SEM analyses reveal that all samples show acicular and elongated columnar crystals of pure calcite (Figure 5) with a preferential orientation developing upwards with respect to the bedrock surface. Crystals develop into a typical radial-growth texture on convex laminae suggesting precipitation from a saturated carbonate solution (Liu et al., 2005). 

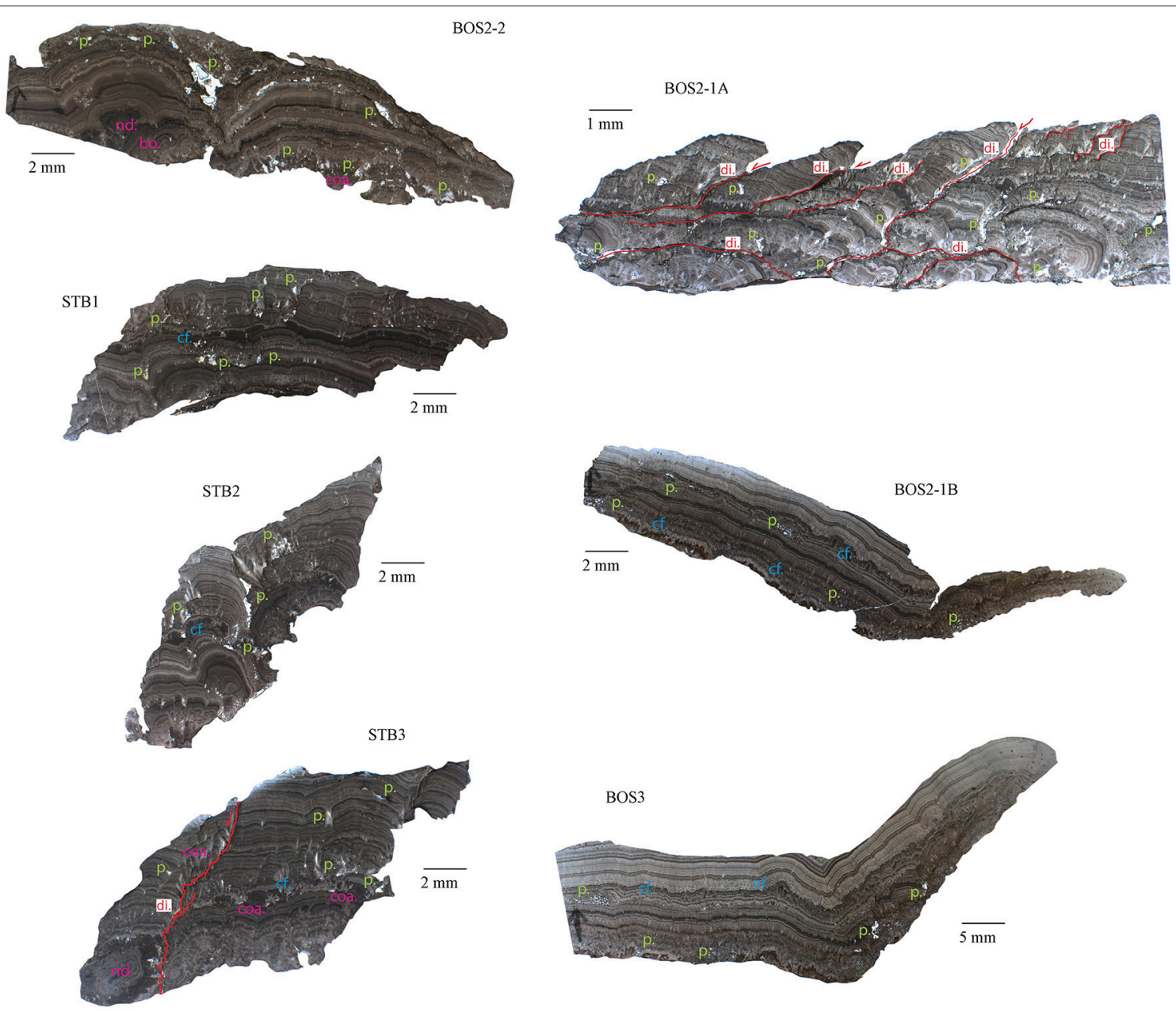

FIGURE 3 | Sedimentary structures identified within samples BOS2-1A, BOS2-1B, BOS3, BOS2-2, STB1, STB2, and STB3. Symbols: p., porosity; di., dissolution structures; cf., fibrous calcite; bo., botryoid; coa., coalescent fabric; nd., nodular fabric.

\section{Petrology and Mineralogy}

Five cryocarbonate samples, two bedrock samples and the layer at the interface between the basement rock and cryocarbonates (i.e., glacial flour) were investigated for their bulk mineralogy. Petrographic investigations were also performed on the two bedrock samples in order to complete the mineralogical investigations carried out via XRD analyses (Table 2). The cryocarbonate samples are essentially composed of calcite, while three of them present accessory minerals such as quartz, plagioclase-type feldspars, phyllite (micas, illite, chlorite), amphiboles (hornblende), and pyroxenes (aegyrine; Table 2, Figure 6) that probably originate from bedrock debris trapped at the interface between the basement rock and cryocarbonates. Of these three samples the BOS 2-2 sample shows a higher proportion of bedrock-inherited minerals. Bedrock samples BOS2-1C and BOS2-1D are mainly composed of silicates (quartz, micas, feldspars, amphiboles, and pyroxenes) with traces of calcite, ankerite and pyrite; this mineralogical paragenesis is typical of the Mont-Blanc granito-gneissic basement. The clay fraction $(<2 \mu \mathrm{m})$ measured on these bedrock samples shows a typical illite and Fe-rich chlorite mineral association. These mineralogical features are confirmed by petrological investigations using a polarizing microscope that allow us to classify BOS2-1C as an amphibolite and BOS2-1D as an augen gneiss (Figure 7), which is consistent with macroscopic observations performed in the field. Thin section observations highlight a net weathering of eroded clasts of the primary ferromagnesian minerals (such as green hornblende, biotite, or aegyrine crystals) and plagioclases into Fe-chlorite and carbonates (Figure 7). The glacial flour deposit overlying the bedrocks is composed of an intermediate mineralogy, including silicate phases consistent with the parent rock (phyllite, quartz, plagioclase, hornblende) and calcite (Table 2, Figure 6). The clay fraction mineralogy of this layer is mainly composed of a typical well-crystallized illitechlorite association but also includes illite-smectite R1 type mixed layers. These observations suggest an input of clays from sedimentary deposits or highly weathered primary clay minerals from in-situ rocks during metamorphic-metasomatic processes. 

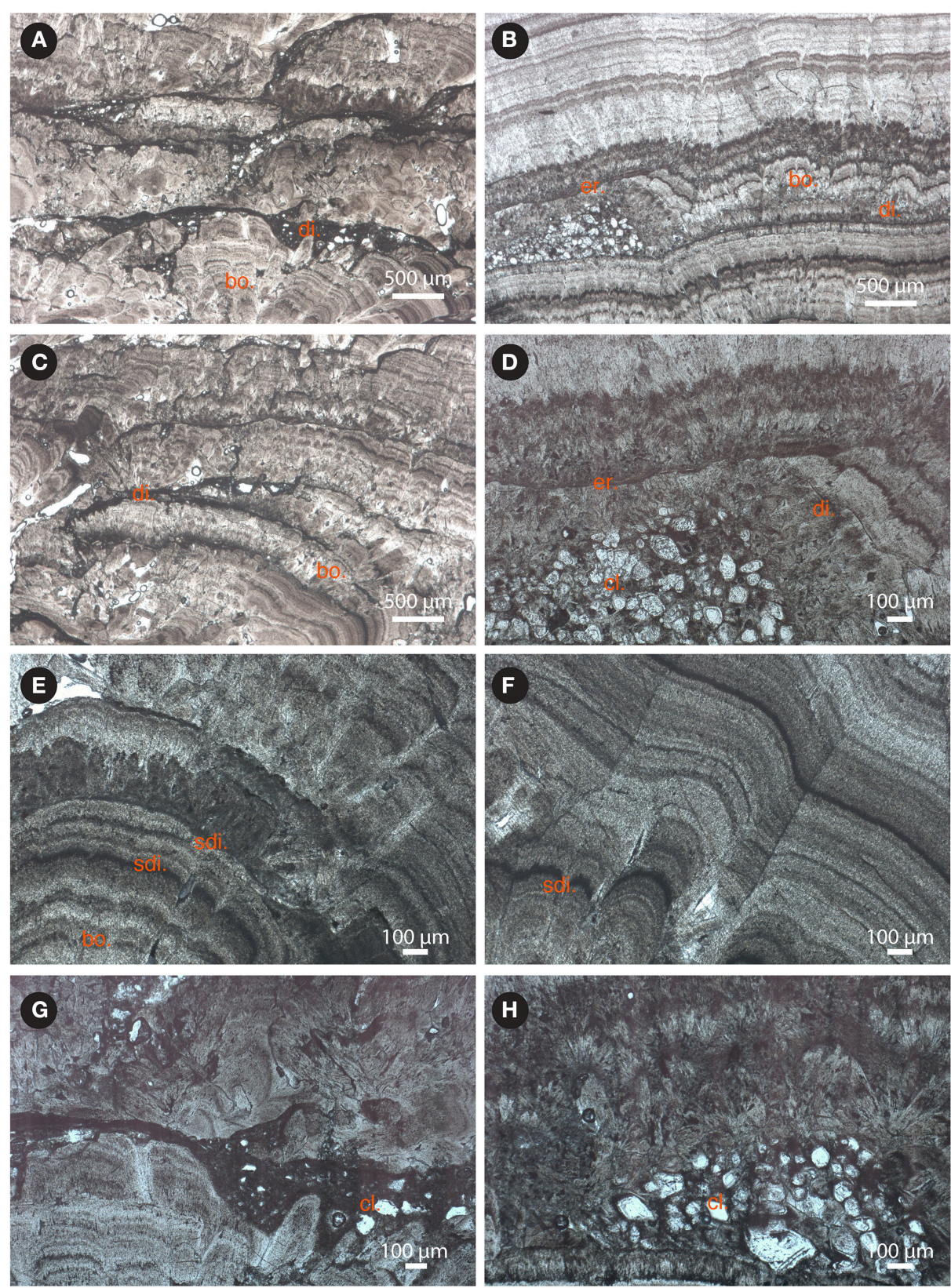

FIGURE 4 | Close-up views of cement layers by the BOS2-1A, BOS2-1B, BOS3, and STB3 samples (see Figure 3 for larger views; di., dissolution structures; sdi., slight dissolution structures; bo., botryoid; er., erosion surface; cl., clastic sediments): (A) successive layers of acicular calcite cements organized in fans interrupted by erosion and dissolution cavities infilled by clastic sediments (BOS2-1B); (B) alternating dark- and light- colored bands trapping clastic accumulation (BOS3); (C) the cemented layer contacts are dissolved and underlined by fine clastic sediments (BOS2-1A); (D) details of the truncated surface covered by new cemented layers (BOS3); (E) botryoid morphology of the acicular calcite cements (STB3); (F) details of the alternating light-colored and black-colored bands in the same layer interrupted by a slight dissolution phase (STB3); (G) fine clastic (argillaceous) infillings trapped between two different cemented layers (BOS2-1A); (H) coarse clastic accumulation (quartz grains with local overgrowth) trapped between two different cemented layers (BOS2-1B). Scale bar is given in the lower-right corner in each panel.

\section{Radiocarbon Dating and Stable Isotope Results}

The total organic carbon radiocarbon dating of sample STB1 gives a depositional conventional age between 6,660 and 6,490 years cal $\mathrm{BP}(1 \sigma)$ and a $\delta^{13} \mathrm{C}_{\text {org }}$ value of $-24.1 \pm 0.2 \%$ o $(1 \sigma)$.
Bulk sample isotopic analyses (Table 3) show a carbonate concentration ranging between 85 and 100 wt.\%. The bulk carbonate $\delta^{13} \mathrm{C}$ and $\delta^{18} \mathrm{O}$ values are similar and vary between -11.6 and $-10.7 \%$ (VPDB) and between 14.2 and $15.2 \%$ (VSMOW), respectively. The resulting $\Delta{ }^{13} \mathrm{C}_{\text {org-carb }}$ is around 

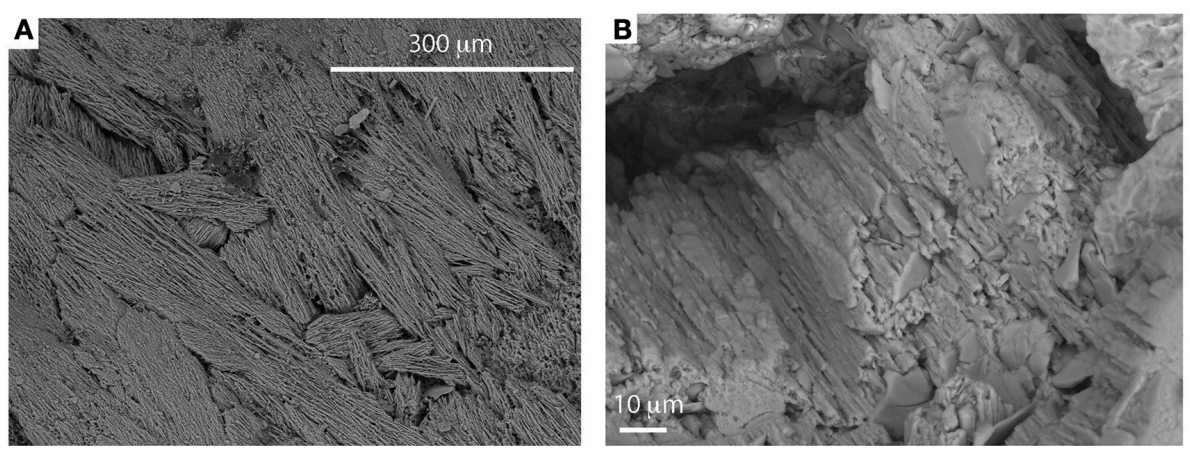

FIGURE 5 | Low-resolution (A) and high-resolution (B) SEM backscatter images of the acicular and elongated columnar calcites crystals from sample BOS2-2. The EDS analyses of this sample reveal stoichiometric calcite.

\begin{tabular}{|c|c|c|c|c|}
\hline $\begin{array}{l}\text { Sample } \\
\text { name }\end{array}$ & Type & $\begin{array}{l}\text { Main phase } \\
\text { (XRD) }\end{array}$ & $\begin{array}{l}\text { Minor phase } \\
\text { (XRD) }\end{array}$ & $\begin{array}{l}\text { Trace phase } \\
\text { (XRD) }\end{array}$ \\
\hline BOS1 & Glacial flour & Calcite & $\begin{array}{l}\text { Phyllite (illite, micas, } \\
\text { chlorite), quartz, } \\
\text { plagioclase }\end{array}$ & Hornblende \\
\hline BOS2-1A & Cryocarbonate & Calcite & - & Phyllite \\
\hline BOS2-1B & Cryocarbonate & Calcite & Plagioclase & Phyllite \\
\hline BOS2-1C & $\begin{array}{l}\text { Amphibolite } \\
\text { (bedrock) }\end{array}$ & $\begin{array}{l}\text { Hornblende, } \\
\text { Fe-chlorite, } \\
\text { plagioclase, }\end{array}$ & $\begin{array}{l}\text { Muscovite, illite, } \\
\text { quartz }\end{array}$ & $\begin{array}{l}\text { Calcite, ankerite, } \\
\text { pyrite, aegyrine }\end{array}$ \\
\hline BOS2-1D & $\begin{array}{l}\text { Gneiss } \\
\text { (bedrock) }\end{array}$ & $\begin{array}{l}\text { Plagioclase, } \\
\text { muscovite, } \\
\text { quartz }\end{array}$ & Fe-chlorite & Aegyrine \\
\hline BOS2-2 & Cryocarbonate & Calcite & $\begin{array}{l}\text { Phyllite (illite, micas, } \\
\text { chlorite), quartz, } \\
\text { plagioclase }\end{array}$ & - \\
\hline BOS3 & Cryocarbonate & Calcite & - & - \\
\hline STB1 & Cryocarbonate & Calcite & - & - \\
\hline
\end{tabular}

$12 \%$. The microsampling of the cryocarbonate laminations (Table 3, Figure 8) shows that both the carbon and oxygen isotopic compositions are homogeneous in the different carbonate precipitation phases. The isotopic values determined by microsampling are consistent with those measured for the bulk samples (Table 3). No temporal evolution of the isotope ratios has been observed and again, the measured values are similar from sample to sample (Figure 8).

\section{Epifluorescence and Confocal Laser Scanning Microcopy and Raman Spectroscopy}

Samples STB1, BOS3, and BOS2-2 were investigated using epifluorescence microscopy, Confocal Laser Scanning Microcopy (CLSM) and Raman laser spectroscopy in order to search for microbial and organic remains. Overall, the sample STB1 shows a strong fluorescence (Figures 9A,B) under UV excitation using epifluorescence microscopy. Only few regions of discrete fluorescence (Figure 9C) were observed using CLSM and a laser excitation between 403 and $633 \mathrm{~nm}$. This fluorescence is the baseline signal linked to the synthetic resin used during sample preparation for thin sections (as confirmed by Raman spectra) and laser reflection. The same feature arises from sample BOS3, pointing to the absence of remnant microorganisms.

Unprepared, fresh, slab of the rock containing BOS2-2 was also studied. This sample shows a strong auto-fluorescence under UV excitation and only small and limited fluorescence spots are observed using CLSM (Figure 9D). We performed two Raman spectra: one in a dark globule associated with a thin micritic laminae (Figure 9E) and the other in the surrounding auto-fluorescent fibrous sparitic calcite (Figure 9F). These Raman spectra show that organic remains are associated with the dark non-fluorescent globule but are not observed in the surrounding calcite. The dark globule Raman spectrum (Figure 9E) is consistent with recent and poorly mature insoluble organic matter.

\section{DISCUSSION}

\section{Origin of the Bossons Glacier Cryocarbonates}

The observed cryocarbonate samples show all of the characteristics of the previously reported occurrences of SPCCs. They are observed on the lee side of roches-moutonées (Figure 2B; Lacelle, 2007); they show a fluted surface parallel to the direction of the ice flow (Figure 2B; $\mathrm{Ng}$ and Hallet, 2002); they are laminated (Figure 3; with dark- and light-colored bands) and composed of micritic and fibrous sparitic calcite crystals (Figures 4, 5).

The outcropping basement of the Bossons glacier is made up of poly-metamorphic (gneiss and micaschist) rocks from the Mont Blanc Massif. No limestones have been observed during the course of this study or reported in the literature, to our knowledge, in this area, but amphibolite shows trace amounts of calcite (Table 2, Figure 6). The SPCCs at Bossons glacier are thus the first cryocarbonates observed on igneous and metamorphic bedrock in Europe. The sources of calcium in the Bossons glacier SPCCs were likely derived from the 


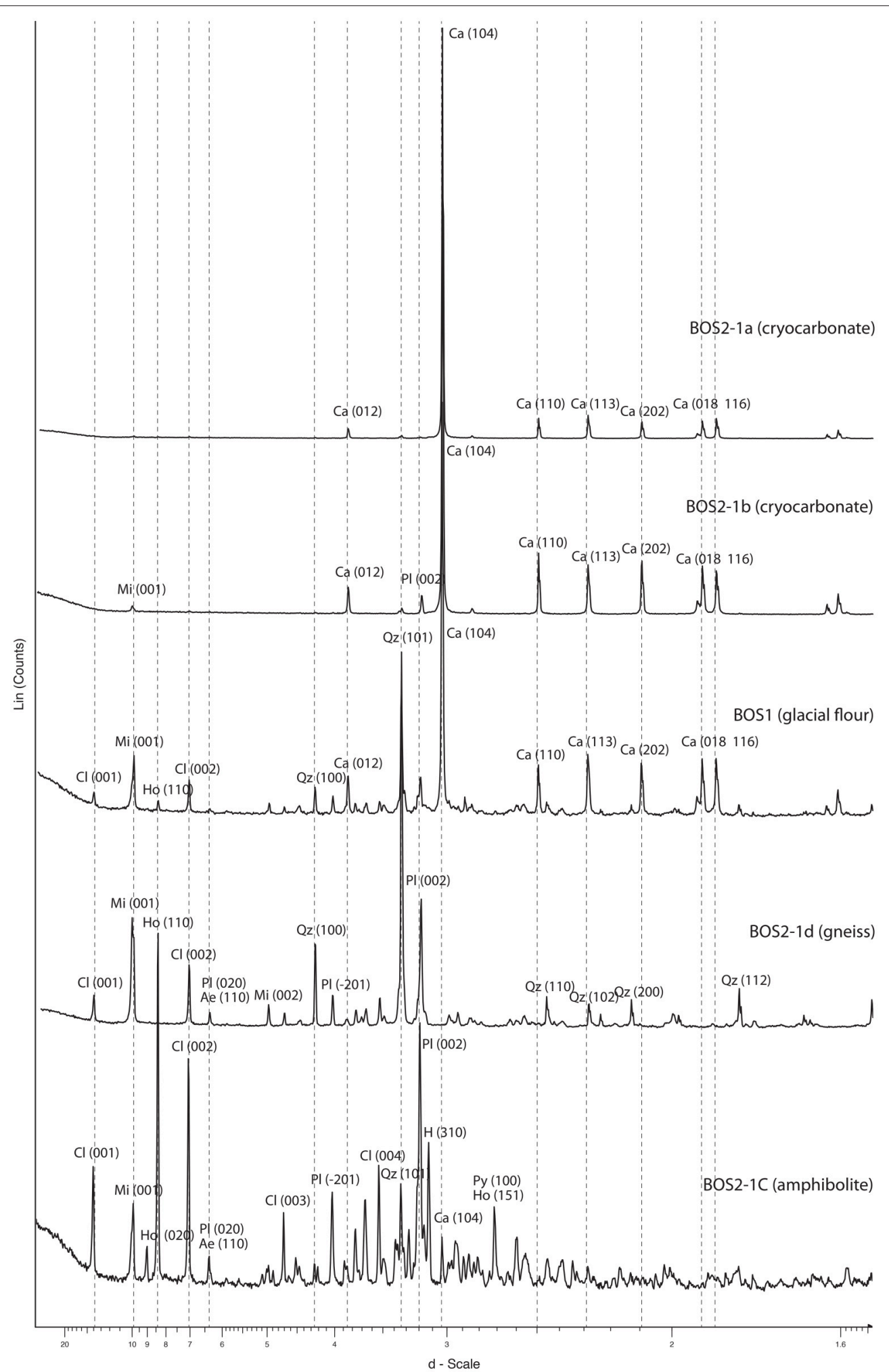

FIGURE 6 | XRD diagrams reflecting the bulk composition of cryocarbonate and bedrock samples. All diagrams are corrected using the (100) diffraction peak of quartz (4.257 $\AA$ ) or (104) the diffraction peak of calcite (3.035 $\AA$ ). Abscissa, expressed in angstrom ( $\AA$ ), represent an interatomic separation of the crystalline sheets; ordinate, expressed as counts of $\mathrm{X}$ photons, represents the intensity. The mineralogical phases associated with peaks are labeled (Ae, aegyrine; $\mathrm{Ca}$, calcite; $\mathrm{Cl}$, Chlorite; Ho, Hornblende; Mi, micas PI, plagioclase; Py, pyrite; Qz, quartz) as well as the nature of the crystalline sheets (Miller index in brackets). The intensity of the main diffraction peaks is proportional to the mineralogical phase contents. 

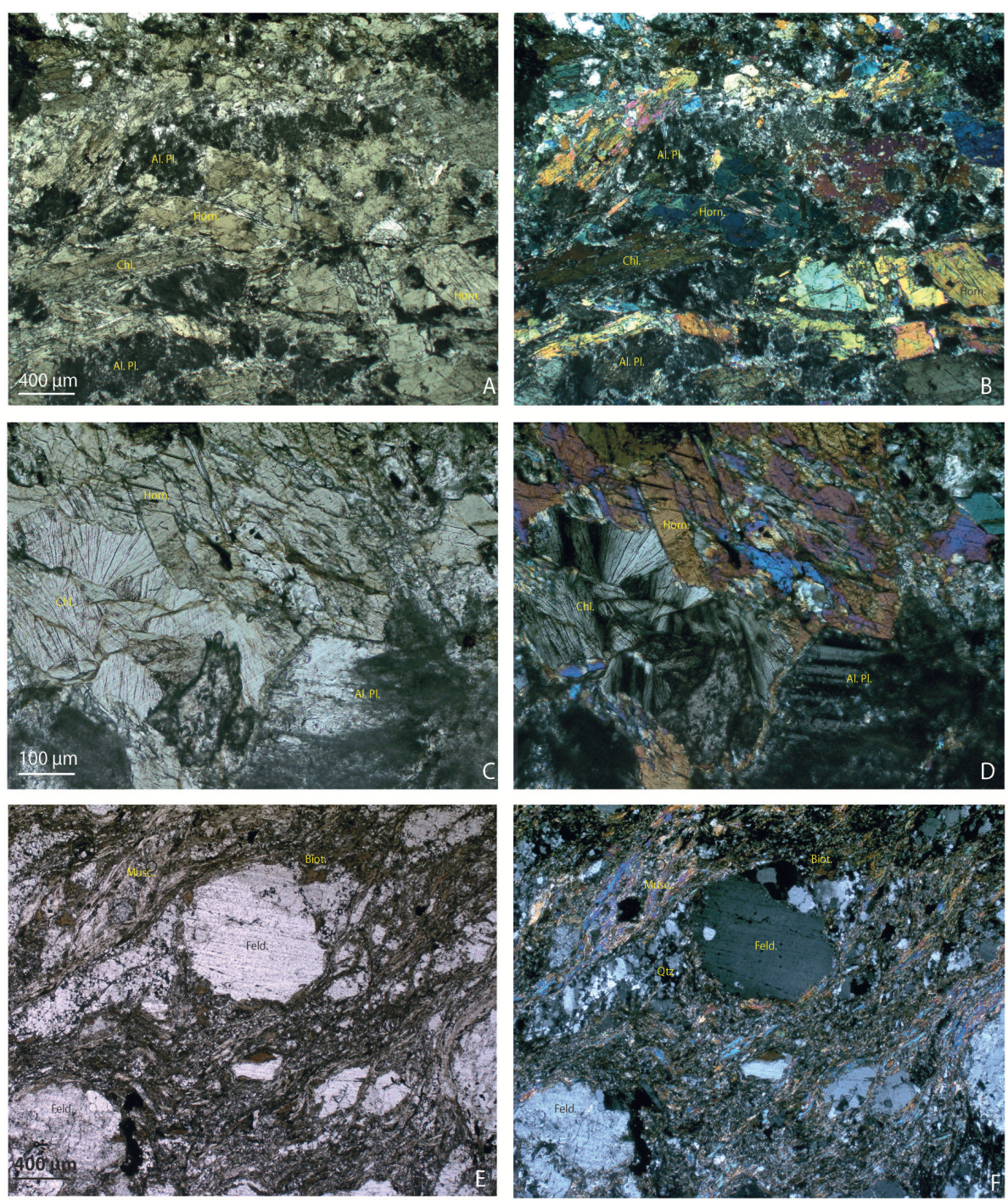

FIGURE 7 | Thin sections of the Bossons bedrock samples under a microscope. (A) amphibolite BOS2-1C showing altered plagioclase (Al. PI.), green hornblende (Horn.), and abundant chlorite; (B) the same view under polarized light; (C) details of the same sample BOS2-1C showing altered hornblende partially replaced by chlorite and altered feldspars (plagioclase with typical polysynthetic twinning observed under polarized light); (D) the same view under polarized light; (E) thin sections of coarse-grained "augen" gneiss BOS2-1D show characteristic shearing structure with elliptic feldspar porphyroclasts (Feld.) within the layerings of the quartz (Qtz), biotite (Biot.), and muscovite (Musc.) bands; (F) the same view under polarized light.

hydrolysis of calcium-bearing silicates such as plagioclase and green hornblende-type amphiboles [e.g., $\mathrm{CaAl}_{2} \mathrm{Si}_{2} \mathrm{O}_{8}+2 \mathrm{H}^{+}$ $\left.+2 \mathrm{OH}^{-} \rightarrow \mathrm{Al}_{2} \mathrm{Si}_{2} \mathrm{O}_{6}(\mathrm{OH})_{2}+\mathrm{Ca}(\mathrm{OH})_{2}\right]$. This is consistent with the XRD and petrographical results showing: (i) clear dissolution of plagioclase and hornblende in bedrock samples and their replacement by clay minerals such as Fe-chlorite devoid of calcium, and (ii) the presence of calcite recrystallization as secondary minerals resulting from the weathering and dissolution of Ca-rich feldspars (Figure 7).

The sources of $\mathrm{HCO}_{3}^{-}$may include (i) gaseous $\mathrm{CO}_{2}$ dissolved in snow and enclosed within bubbles in the ice, (ii) oxidation of organic carbon, or (iii) dissolution of trace calcite within local granite-gneissic bedrocks. The common genetic model assumed that SPCCs precipitate when the meltwater becomes saturated with $\mathrm{CaCO}_{3}$ on the lee side of an obstacle during the regelation process (Hallet, 1976; Hanshaw and Hallet, 1978; Souchez and Lemmens, 1985). The Bossons glacier is a polythermal glacier and refreezing processes occur in basal cavities, as observed in other present-day alpine glaciers such as the Argentière glacier in the Mont Blanc Massif (Vivian and Bocquet, 1973) or Tsanfleuron glacier in Switzerland (Souchez and Lemmens, 1985). The regelation process might take place only when the basal ice pressure drops (Liu et al., 2005), for instance on the lee side of an obstacle. Meltwater from the Crosette stream shows bicarbonate and calcium concentrations ranging from 10 to 70 and 6 to $50 \mathrm{mg} / \mathrm{l}$, respectively (J.F. Buoncristiani pers. comm.). 
TABLE 3 | Bulk and microsampling stable isotope results.

\begin{tabular}{|c|c|c|c|}
\hline Sample name & $\begin{array}{c}\delta^{13} \mathrm{C} \text { vsVPDB } \\
\% \text { o }\end{array}$ & $\begin{array}{c}\delta^{18} \mathrm{O} \text { vs.VSMOW } \\
\% \text { क }\end{array}$ & $\begin{array}{c}\text { Calcite } \\
\text { wt. } \%\end{array}$ \\
\hline \multirow[t]{2}{*}{ BOS2-1A bulk } & -11.4 & 14.6 & 92 \\
\hline & -11.3 & 15.2 & 87 \\
\hline BOS2-1AX1 & -12.2 & 14.9 & - \\
\hline BOS2-1A X2 & -12 & 14.7 & - \\
\hline BOS2-1A Y1 & -11.7 & 14.5 & - \\
\hline BOS2-1A Y2 & -11.2 & 15.8 & - \\
\hline BOS2-1A Z1 & -11.3 & 14.7 & - \\
\hline BOS2-1A Z2 & -11.4 & 14.8 & - \\
\hline \multirow[t]{2}{*}{ BOS2-1B bulk } & -10.8 & 14 & 100 \\
\hline & -10.6 & 14.5 & 85 \\
\hline \multirow[t]{2}{*}{ BOS2-2 bulk } & -11.6 & 14.5 & 100 \\
\hline & -11.3 & 15.2 & 100 \\
\hline BOS2-2 U1 & -11.7 & 15.7 & - \\
\hline BOS2-2 U2 & -12.1 & 15.8 & - \\
\hline BOS2-2 V1 & -11.9 & 15.2 & - \\
\hline BOS2-2 V2 & -11.7 & 15.2 & - \\
\hline BOS2-2 W1 & -11.5 & 15.1 & - \\
\hline BOS2-2 W2 & -11.1 & 15.4 & - \\
\hline \multirow[t]{2}{*}{ BOS3 bulk } & -10.8 & 14.2 & 100 \\
\hline & -10.7 & 14.7 & 100 \\
\hline BOS3 G1 & -10.5 & 14.0 & - \\
\hline BOS3 G2 & -11.1 & 15.3 & - \\
\hline BOS3 H1 & -11 & 15.2 & - \\
\hline BOS3 H2 & -10.5 & 14.4 & - \\
\hline STB1 bulk & -11.4 & 15.2 & 100 \\
\hline
\end{tabular}

These values are far from calcite saturation and we argue that the SPCCs reported in this study precipitated during the process of regelation, which concentrates ions up to saturation in the basal meltwater of the Bossons glacier.

\section{Carbon and Oxygen Isotopic Signals}

The mean $\delta^{18} \mathrm{O}$ value of the Bossons-glacier SPCCs is $14.9 \pm$ $0.5 \%$ o ( $1 \sigma$, VSMOW), for bulk and microsampling measurements (Table 3). The oxygen isotope values are relatively similar in successive laminae (Figure 8), suggesting precipitation at equilibrium in an open system condition with the regelation ice and that Rayleigh-type fractionation during freezing did not adversely alter the basal meltwater oxygen isotopic composition. This is consistent with the open system subglacial hydrologic models of Aharon (1988) and Sharp et al. (1990). Precipitation at quasi equilibrium conditions is suggested by the presence of acicular and elongated columnar crystal calcite fabric in all samples (Frisia et al., 2000; Frisia, 2015). The dominance of sparite over micrite in the Bossons-glacier SPCCs also indicates for calcite precipitation under open-system subglacial hydrologic conditions (Sharp et al., 1990).

The mean $\delta^{13} \mathrm{C}$ value of the Bossons-glacier SPCCs is $-11.3 \pm 0.5 \%$ o (1 $\sigma, \mathrm{VPDB})$, for the bulk and microsampling measurements (Table 3). Following the precipitation of the
SPCCs at equilibrium with the basal ice at $0^{\circ} \mathrm{C}$ and neutral $\mathrm{pH}$, the expected calcite carbon isotopic composition should be enriched in ${ }^{13} \mathrm{C}$ by $\sim 12 \%$ relative to $\mathrm{CO}_{2}$ (Romanek et al., 1992). Accordingly, carbon sourcing from dissolved gaseous $\mathrm{CO}_{2}$ in snow and bubbles is not possible here because, given an atmospheric $\mathrm{CO}_{2}$ isotopic composition during the Holocene pre-industrial period of around $-6.45 \%$ o (Indermühle et al., 1999), the $\delta^{13} \mathrm{C}$ value at equilibrium estimated for the SPCCs would be around $12-6.45=5.55 \%$. The possibility that the carbon is sourced from trace carbonates within the local bedrock is unlikely here because the Bossons glacier catchment area is mainly composed of Mont Blanc calc-alkaline granite, poly-metamorphic gneiss and micaschist (Bussy et al., 1989). Moreover, sedimentary carbonates or metasomatic and metamorphic carbonates (e.g., fracture filling by late stage fluids) have never been described or observed in the study area and represent only trace amount in the studied bedrocks samples (Table 2, Figure 6). A minute amount of secondary calcite is observed in the thin sections and associated with the alteration of plagioclases from the weathered bedrocks but is unlikely to be a significant source of carbon in the SPCCs.

Several studies show that subglacial water system could host bacterial communities (Sharp et al., 1999; Foght et al., 2004; Hodson et al., 2008; Lanoil et al., 2009; Christner et al., 2014; Montross et al., 2014; Boetius et al., 2015) that enhance subglacial weathering. Montross et al. (2013) demonstrated the importance of the generation of bicarbonate from microbial respiration of organic matter from subglacial sediments underlain (in part) by gneissic/granitic bedrock in laboratory experiments. Their study demonstrated a 3.3 to 4.7 -fold increase in bicarbonate production in the biotic relative to the abiotic conditions over time periods ranging from 3 to 10 months. Microbial respiration may be consistent with our light $\delta^{13} \mathrm{C}$ record for carbonates. However, in our study, epifluorescence and CLS Microcopy and Raman spectroscopy observations do not support the presence of an active microbial community performing insoluble organic matter oxidation in direct association with SPCCs. Yet, our observations do not preclude that microbial respiration metabolisms occurred in the subglacial sediments upstream of the location where the carbonate precipitation took place.

Finally, carbon could be sourced from the basal meltwater through the combination of abiotic and biotic oxidation of organic material trapped in the subglacial preserved soil. This process has been suggested by Refsnider et al. (2014) to explain the low $\delta^{13} \mathrm{C}$ of around -9\% (VPDB) in the SPCCs from the eastern Canadian Arctic. The carbon isotopic composition measured in organic material of sample STB1, around -24.1 $\pm 0.2 \%$ o $(1 \sigma)$, is fully consistent with the range of the modern upland Alpine (Urseren Valley, southern central Switzerland) soil organic matter from -27 to $-21 \%$ (Schaub and Alewell, 2009). As the soil dissolved gaseous $\mathrm{CO}_{2}$ is usually enriched in ${ }^{13} \mathrm{C}$ by about $4.4 \%$ during diffusion compared to the soil organic matter (Davidson, 1995; Refsnider et al., 2014), if we hypothesize that the STB1 organic carbon $\delta^{13} \mathrm{C}$ is representative of the carbon source for the SPCCs, then we can calculate that the $\mathrm{CO}_{2}$ produced during the oxidation of this organic carbon might have had an isotopic composition around $-24.1+4.4$ 

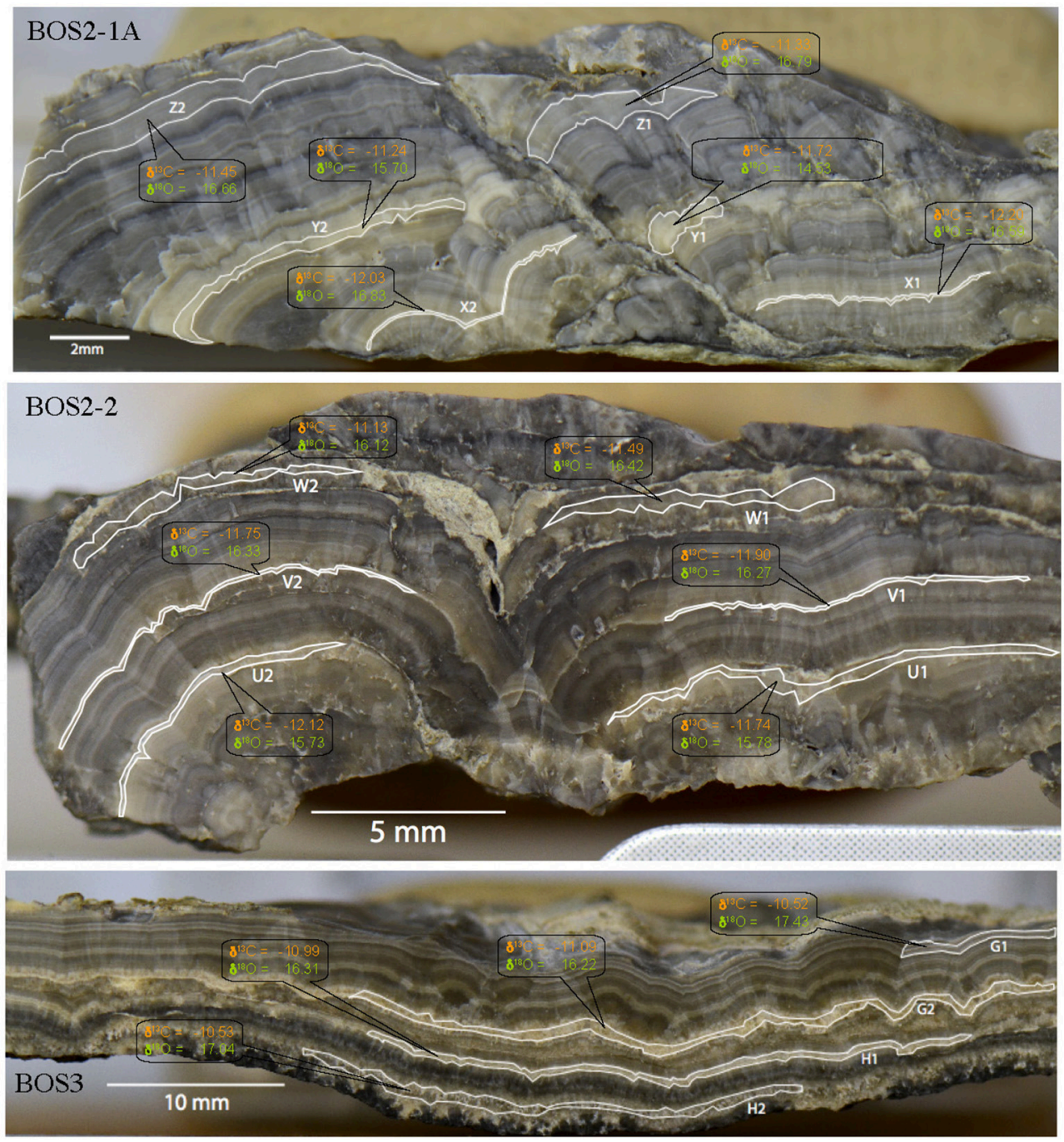

FIGURE 8 | Carbon and oxygen isotope values for the carbonate within samples BOS2-1A, BOS2-2, BOS3. Isotopic values are reported in the standard $\delta$-notation in permil (\%) relative to VPDB and VSMOW for the carbon and oxygen isotopes, respectively.

$=-19.7 \%$. The precipitation of the SPCCs at equilibrium, at $0^{\circ} \mathrm{C}$ and neutral $\mathrm{pH}$, with a carbon dioxide isotopic composition of about $-19.7 \%$ would then translate into a cryocarbonate carbon isotopic composition of about $-19.7+12=-7.7 \%$. This calculated value is $3.6 \%$ heavier than the mean $\delta^{13} \mathrm{C}$ value for the Bossons glacier SPCCs measured in this study. However, rapid calcite precipitation can exert an additional kinetic enrichment of up to $-4 \%$ (Turner, 1982) and we cannot exclude here the involvement of a microbial community in the organic matter oxidation process. We propose that the $\mathrm{C}$ incorporated in the SPCCs was largely derived from old soil organic carbon that was converted into dissolved inorganic carbon through a combination of biotic and abiotic oxidation processes, with minor contributions from other sources. These proposed mechanisms for the formation of the Bossons glacier SPCCs is consistent with the one suggested by Refsnider et al. (2014) for explaining the low $\delta^{13} \mathrm{C}$ record for the SPCCs from the eastern Canadian Arctic, and consistent with the model experiments performed by Mitchell and Brown (2008), who showed a large contribution of subglacial trapped soil organic carbon to the subglacial meltwater carbon reservoir.

\section{Implications for the Holocene Paleoclimate in the Bossons Area}

The carbon isotopic compositions of the SPCCs show that the "dissolved inorganic" C required for the Bossons Glacier cryocarbonate precipitation is largely derived from organic material trapped in soils overridden by the glacier and oxidized in the subglacial environment. The development of a proglacial soil accumulating a large amount of organic material implies that the glacier was in a retracted position, above our sampling site (at 1,760 $\mathrm{m}$ a.s.l.; Fig. 10), possibly for several hundreds of years (Egli et al., 2006). Therefore, assuming that the organic carbon enclosed within our cryocarbonate samples reflects the 

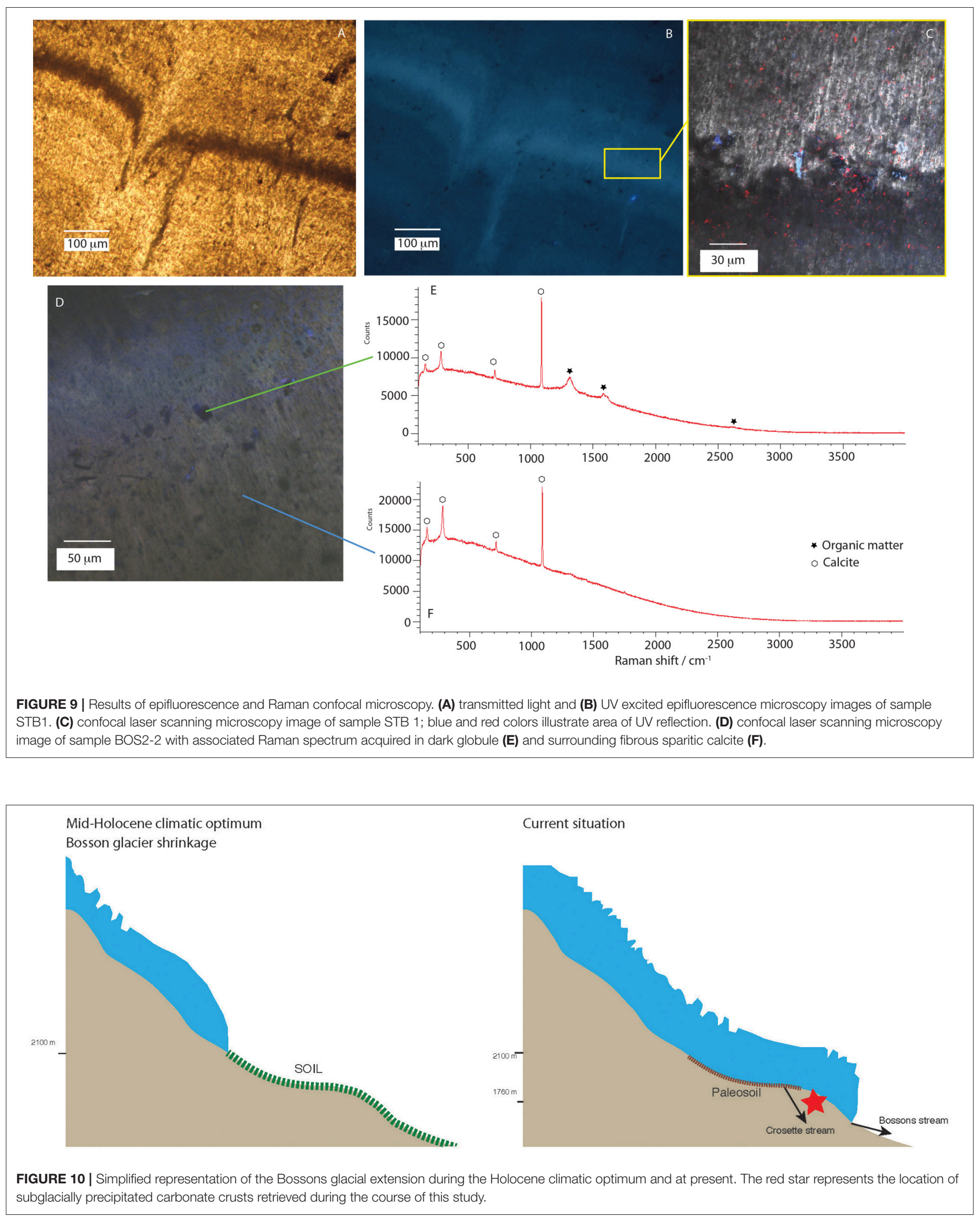
soil organic carbon, we can deduce the minimum age of the primary paleosol development to be around 6,500 years cal BP. This time period is consistent with the Holocene warming period between roughly 9,300 and 6,000 years cal BP recorded in the Apennines and central Italy (Giraudi et al., 2011). In further detail, it is consistent with period III, between 7,400 and 5,700 years cal BP, described by Arnaud et al. (2012) as a period of high clastic input in the alpine Lake Bourget following soil development in the catchment area. Indeed, the main source area of clastic particles for Lake Bourget over the last 9,400 years cal BP is the upper part of the Arve River drainage basin, which includes the glaciers from the Mont Blanc Massif (Debret et al., 2010). This is also in agreement with the hypothesis that this part of the Holocene records a pedological optimum during which soils developed on alpine terrenes at an altitude of at least $2,100 \mathrm{~m}$ above sea level (Giguet-Covex et al., 2010; Mourier et al., 2010; see Figure 10). Therefore, the SPCCs might record a widely untapped source of information about the Holocene paleoclimatic oscillations and their consequences on high altitude soil development.

\section{CONCLUSIONS}

The cryocarbonates from the Bossons glacier observed in this study are SPCCs. The precipitation of large crystals of radial fibrous sparite is favored when basal meltwater becomes saturated with $\mathrm{CaCO}_{3}$ during the regelation process due to pressure fluctuations on the lee side of roche moutonées. The sources of calcium in the Bossons glacier SPCCs are likely derived from chemical weathering of calcium silicate minerals from the granito-gneissic basements of the Mont Blanc Crystalline Massif.

\section{REFERENCES}

Aharon, P. (1988). Oxygen, carbon, and U-series isotopes of aragonites from Vestfold Hills, Antarctica: clues to geochemical processes in subglacial environments. Geochim. Cosmochim. Acta 52, 2321-2331. doi: 10.1016/0016-7037(88)90134-2

Arnaud, F., Révillon, S., Debret, M., Revel, M., Chapron, E., Jacob, J., et al. (2012). Lake Bourget regional erosion patterns reconstruction reveals Holocene NW European Alps soil evolution and paleohydrology. Quat. Sci. Rev. 51, 81-92. doi: 10.1016/j.quascirev.2012.07.025

Boetius, A., Anesio, A. M., Deming, J. W., Mikucki, J. A., and Rapp, J. Z. (2015). Microbial ecology of the cryosphere: sea ice and glacial habitats. Nat. Rev. Microbiol. 13, 677-690. doi: 10.1038/nrmicro 3522

Bunting, B. T., and Christensen, L. (1978). Micromorphology of calcareous crusts from the Canadian High Arctic. Geologiska Foreningens Forhandlinger 100, 361-367. doi: 10.1080/11035897809454476

Bussy, F., Schaltegger, U., and Marro, C. (1989). The age of the Mont-Blanc granite (Western Alps): a heterogeneous isotopic system dated by $\mathrm{Rb}-\mathrm{Sr}$ whole rock determinations on its microgranular enclaves. Schweiz. Mineral. Petrogr. Mitt. 69, 3-13.

Cannic, S., Lardeaux, J. M., Mugnier, J. L., and Hernandez, J. (1996). Tectonometamorphic evolution of the Roignais-Versoyen zone. Eclogae Geol. Helv. 89, 321-345.

Christner, B. C., Priscu, J. C., Achberger, A. M., Barbante, C., Carter, S. P., Christianson, K., et al. (2014). Subglacial Lake Whillans: a microbial
Measured abundances of carbon and oxygen isotopes suggest the precipitation of SPCCs at, or near to, equilibrium in open system conditions. Homogeneous low $\delta^{13} \mathrm{C}$ values of the SPCCs (around $-11.3 \%$ ) argue for a large contribution of soil organic carbon to the Bossons glacier subglacial meltwater inorganic carbon reservoir at the time of deposition. Organic remains trapped in the Bossons glacier SPCCs underline our inference that (i) the high alpine environment was sensitive to Holocene warming, (ii) soil and vegetation developed at significantly higher altitudes during the Mid-Holocene climatic and pedological optimum than today at the sampling site, and (iii) climatic temperatures in our study area before around 6,500 years cal BP were similar, if not higher, than today, at an altitude above $1,760 \mathrm{~m}$.

\section{AUTHOR CONTRIBUTIONS}

CT, JB, EV, and PP participated to the conception of the work. CT, JB, EV, PP, TC, JM, and EG participated to the data collection, the data analysis and interpretation, and drafting of the article.

\section{ACKNOWLEDGMENTS}

This work is a contribution to the ANR project VIP-MontBlanc (ANR-14-CE03-0006). We gratefully acknowledge support from the Université de Bourgogne FABER Program (France) and the Institut National des Sciences de l'Univers (CNRS, France). We would like to thank Anaïs Daburon for assistance in the laboratory and field, Frédéric Hebst for SEM expertise and Philippe Blanc for the thin sections. We also thank the reviewers for their constructive comments and Elodie, whose contributions was critical to this discovery. Felix $\mathrm{Ng}$ is acknowledged for handling this manuscript and for numerous helpful suggestions. ecosysytem beneath the West Antarctic Ice Sheet. Nature 512, 310-313. doi: $10.1038 /$ nature 13667

Clark, I. D., Lauriol, B., Marschner, M., Sabourin, N., Chauret, Y., and Desrochers, A. (2004). Endostromatolites from permafrost karst, Yukon Canada: paleoclimatic proxies for the Holocene thermal hypsithermal. Can. J. Earth Sci. 41, 387-399. doi: 10.1139/e04-014

Davidson, G. R. (1995). The stable isotopic composition and measurement of carbon in soil $\mathrm{CO}_{2}$. Geochim. Cosmochim. Acta 59, 2485-2489. doi: 10.1016/0016-7037(95)00143-3

Debret, M., Chapron, E., Desmet, M., Rolland-Revel, M., Magand, O., Trentesaux, A., et al. (2010). North western Alps Holocene paleohydrology recorded by flooding activity in lake Le Bourget, France. Quat. Sci. Rev. 29, 2185-2200. doi: 10.1016/j.quascirev.2010.05.016

Egli, M., Wernli, M., Kneisel, C., and Haeberli, W. (2006). Melting glaciers and soil development in the proglacial area Morteratsch (Swiss Alps): I. Soil type chronosequence. Arct. Antarct. Alpine Res. 38, 499-509. doi: 10.1657/15230430(2006)38[499:MGASDI]2.0.CO;2

Fairchild, I. J., Bradly, L., and Spiro, B. (1993). Carbonate diagenesis in ice. Geology 21, 901-904. doi: 10.1130/0091-7613(1993)021\&lt;0901:CDII\&gt; 2.3.CO;2

Fairchild, I. J., Brady, L., and Spiro, B. (1994). "Reactive carbonate in glacial systems: a preliminary synthesis of its creation, dissolution and reincarnation," in Earth's Glacial Record, eds M. Deynoux, J. M. G.Miller, E. W. Domack, N. Eyles, I. J. Fairchild, and G. M. Young (Cambridge University Press), 176-192.

Fallourd, R., Harant, O., Trouve, E., Nicolas, J. M., Gay, M., Walpersdorf, A., et al. (2011). Monitoring temperate glaciers by multi-temporal TerraSAR-X images 
and continuous GPS measurements. IEEE J. Sel. Top. Appl. Earth Obs. Remote Sensing 4, 372-386. doi: 10.1109/JSTARS.2010.2096200

Foght, J., Aislabie, J., Turner, S., Brown, C. E., Ryburn, J., Saul, D. J., et al. (2004). Culturable bacteria in subglacial sediment and ice from two Southern Hemisphere glaciers. Microb. Ecol. 47, 329-340. doi: 10.1007/s00248-003-1036-5

Ford, D. C., Fuller, P. G., and Drake, J. J. (1970). Calcite precipitates at the sole of temperate glaciers. Nature 226, 441-442. doi: 10.1038/226441a0

Frisia, S. (2015). Microstratigraphic logging of calcite fabrics in speleothems as tool for palaeoclimate studies. Int. J. Speleol. 44, 1-16. doi: 10.5038/1827-806X.44.1.1

Frisia, S., Borsato, A., Fairchild, I. J., and McDermott, F. (2000). Calcite fabrics, growth mechanisms, and environments of formation in speleothems from the Italian Alps and southwestern Ireland. J. Sediment. Res. 70, 1183-1196. doi: 10.1306/022900701183

Giguet-Covex, C., Arnaud, F., Poulenard, J., Enters, D., Reyss, J.-L., and Vidal, O. (2010). Multi proxy reconstruction of trophic state and hypolimnetic anoxia in a large hard-water lake (Lake Bourget, French Alps) over the past 140 years. J. Palaeolimnol. 43, 171-190. doi: 10.1007/s10933-009-9324-9

Giraudi, C., Magny, M., Zanchetta, G., and Drysdale, R. N. (2011). The Holocene climatic evolution of Mediterranean Italy: a review of the continental geological data. Holocene 21, 105-115. doi: 10.1177/09596836103 77529

Godon, C., Mugnier, J., L., Fallourd, R., Paquette, J., L., Pohl, A., and Buoncristiani, J.-F. (2013). The Bossons glacier protects Europe's summit from erosion. Earth Planet. Sci. Lett. 375, 135-147. doi: 10.1016/j.epsl.2013.05.018

Guillon, H., Mugnier, J. L., Buoncristiani, J.-F., Carcaillet, J., Godon, C., Prud'homme, C., et al. (2015). Improved discrimination of subglacial and periglacial erosion using $10 \mathrm{Be}$ concentration measurements in subglacial and supraglacial sediment load of the Bossons glacier (Mont Blanc massif, France). Earth Surf. Process. Landforms 40, 1202-1215. doi: 10.1002/esp.3713

Hallet, B. (1976). Deposits formed by subglacial precipitation of $\mathrm{CaCO} 3$. Geol. Soc. Am. Bull. 87, 1003-1015. doi: 10.1130/0016-7606(1976)87<1003: DFBSPO $>2.0 . \mathrm{CO} ; 2$

Hanshaw, B. B., and Hallet, B. (1978). Oxygen isotope composition of subglacially precipitated calcite: possible paleoclimate implications. Science 200, 1267-1270. doi: $10.1126 /$ science.200.4347.1267

Hillaire-Marcel, C., Soucy, J.-M., and Cailleux, A. (1979). Analyse isotopique de concretions sousglaciaires de l'inlandsis laurentidien et teneur en oxygene 18 de la glace. Can. J. Earth Sci. 16, 1494-1498. doi: 10.1139/e79-132

Hodson, A., Anesio, A. M., Tranter, M., Fountain, A., Osborn, M., Priscu, J., et al. (2008). Glacial ecosystems. Ecol. Monogr. 78, 41-67. doi: 10.1890/07-0187.1

Hubbard, B., and Hubbard, A. (1998). Bedrock surface roughness and the distribution of subglacially precipitated carbonate deposits: implications for formation at Glacier de Tsansfleuron, Switzerland. Earth Surf. Process. Landforms 23, 261-270. doi: 10.1002/(SICI)1096-9837(199803)23:3<261::AIDESP848>3.0.CO;2-5

Huss, M., and Farinotti, D. (2012). Distributed ice thickness and volume of all glaciers around the globe. J. Geophys. Res. 117, F04010. doi: 10.1029/2012JF002523.

Indermühle, A., Stocker, T. F., Joos, F., Fischer, H., Smith, H. J.,Wahlen, M., et al. (1999). Holocene carbon-cycle dynamics based on $\mathrm{CO}_{2}$ trapped in ice at Taylor Dome Antarctica. Nature 398, 121- 126.

Killawee, J. A., Fairchild, I. J., Tison, J. L., Janssens, L., and Lorrain, R. (1998). Segregation of solutes and gases in experimental freezing of dilute solutions: implication for natural glacier systems. Geochim. Cosmochim. Acta 62, 3637-3655. doi: 10.1016/S0016-7037(98)00268-3

Lacelle, D. (2007). Environmental setting, (micro)morphologies and stable CØisotope composition of cold-climate carbonate precipitates - a review and evaluation of their potential as paleoclimatic proxies. Quat. Sci. Rev. 26, 1670-1689. doi: 10.1016/j.quascirev.2007.03.011

Lanoil, B., Skidmore, M., Priscu, J. C., Han, S., Foo, W., Vogel, S. W., et al. (2009). Bacteria beneath the West Antarctic Ice Sheet. Environ. Microbiol. 11, 609-615. doi: 10.1111/j.1462-2920.2008.01831.x

Le Meur, E., and Vincent, C. (2006). Monitoring of the Taconnaz ice fall (French Alps) using measurements of mass balance, surface velocities and ice cliff position. Cold Reg. Sci. Technol. 46, 1-11. doi: $10.1016 /$ j.coldregions.2006.05.001
Leloup, P., Arnaud, N., Sobel, E., and Lacassin, R. (2005). Alpine thermal evolution of the highest external crystaline massif: the Mont-Blanc. Tectonics 24, TC4002. doi: 10.1029/2004TC001676

Liu, G., Luo, R., Cao, J., and Cui, Z. (2005). Processes and environmental significance of the subglacial chemical deposits in Tianshan Mountains. Sci. China Ser. D Earth Sci. 48, 1470-1478. doi: 10.1360/02yd0459

Marlin, C., Dever, L., Vachier, P., and Courty, M.-A. (1993). Variations chimiques et isotopiques de l'eau du sol lors de la reprise en gel d'une couche active sur pergélisol continu (Presqu'ile de Brogger, Svalbard). Can. J. Earth Sci. 30, 806-813. doi: 10.1139/e93-066

Mitchell, A. C., and Brown, G. H. (2008). Modeling geochemical and biogeochemical reactions in subglacial environments. Arct. Antarct. Alp. Res. 40, 531-547. doi: 10.1657/1523-0430(06-075)[MITCHELL]2.0.CO;2

Montross, S., Skidmore, M., Christner, B., Samyn, D., Tison, J. L., Lorrain, R., et al. (2014). Debris-Rich basal ice as a microbial habitat, Taylor Glacier, Antarctica. Geomicrobiol. J. 31, 76- 81. doi: 10.1080/01490451.2013. 811316

Montross, S., Skidmore, M., Tranter, M., Kivimäki, A. L., and Parkes, R. J. (2013). A microbial driver of chemical weathering in glaciated systems. Geology 41, 215-218. doi: 10.1130/g33572.1

Mourier, B., Poulenard, J., Carcaillet, C., and Williamson, D. (2010). Soil evolution and subalpine ecosystem changes in the French Alps inferred from geochemical analysis of lacustrine sediments. J. Paleolimnol. 44, 571-587. doi: 10.1007/s10933-010-9438-0

Mugnier, J. L., Guellec, S., Menard, G., and Roure, F. (1989). Géométrie et structures du socle des Alpes externes déduites des profils Ecors-Crop Alpes 1 et Ecors Alpes 2. C. R. Acad. Sci. Paris 309, 733-739.

Neuser, R. D., and Richter, D. K. (2007). Non-marine radiaxial fibrous calcites examples of speleothems proved by electron backscatter diffraction. Sed. Geol. 194, 147-154. doi: 10.1016/j.sedgeo.2006.05.015

Ng, F., and Hallet, B. (2002). Patterning mechanisms in subglacial carbonate dissolution and deposition. J. Glaciol. 48, 386-400. doi: $10.3189 / 172756502781831214$

Parnell, J., Bowden, S. A., Cockell, C. S., Osinski, G. R., and Lee, P. (2006). "Surface mineral crusts: a priority target in search for life on Mars", in Lunar and Planetary Science XXXVII, Abstract 1049, Lunar and Planetary Institute (Houston, TX: CD-ROM).

Refsnider, K. A., Miller, G H., Fogel, M. L., Fréchette, B., Bowden, R., Andrews, J T., et al. (2014). Subglacially precipitated Carbonates record geochemical interactions and pollen preservation at the base of the Laurentide Ice Sheet on central Baffin Island, eastern Canadian Arctic. Q. Res. 81, 94-105. doi: 10.1016/j.yqres.2013.10.014

Romanek, C. S., Grossman, E. L., and Morse, J. W. (1992). Carbon isotopic fractionation in synthetic aragonite and calcite: effects of temperature and precipitation rate. Geochim. Cosmochim. Acta 56, 419-430. doi: 10.1016/0016-7037(92)90142-6

Schaub, M., and Alewell, C. (2009). Stable carbon isotopes as an indicator for soil degradation in an alpine environment (Urseren Valley, Switzerland). Rapid Commun. Mass Spectrom. 23, 1499-1507. doi: 10.1002/rcm. 4030

Sharp, M., Parkes, J., Cragg, B., Fairchild, I. J., Lamb, H., and Tranter, M. (1999). Widespread bacterial populations at glacier beds and their relationship to rock weathering and carbon cycling. Geology 27, 107-110. doi: 10.1130/00917613(1999)027\&lt;0107:WBPAGB\&gt;2.3.CO;2

Sharp, M., Tison, J.-L., and Fierrens, G. (1990). Geochemistry of subglacial calcites: implications for the hydrology of the basal water film. Arct. Alp. Res. 22, 141-152. doi: 10.2307/1551299

Souchez, R. A., and Lemmens, M. (1985). Subglacial carbonate deposition-an isotopic study of present-day case. Palaeogeogr. Palaeoclimatol. Palaeoecol. 51, 357-364. doi: 10.1016/0031-0182(85)90093-8

Suter, S., and Hoelzle, M. (2002). Cold firn in the Mont-Blanc and Monte Rosa areas, European Alps: spatial distribution and statistical models. Ann. Glaciol. 35, 9-18. doi: 10.3189/172756402781817059

Swett, K. (1974). Calcrete crusts in an arctic permafrost environment. Am. J. Sci. 274, 1059-1063. doi: 10.2475/ajs.274.9.1059

Turner, J. V. (1982). Kinetic fractionation of carbon-13 during calcium carbonate precipitation. Geochim. Cosmochim. Acta 46, 1183-1191. doi: 10.1016/0016-7037(82)90004-7 
Vincent, C., Le Meur, E., Six, D., and Possenti, P. (2007). Climate warming revealed by englacial temperature at Col du Dôme (4250 m, MontBlanc area). Geophys. Res. Lett. 34, L16502. doi: 10.1029/2007GL0 29933

Vivian, R., and Bocquet, G. (1973). Subglacial cavitation phenomena under the Glacier d'Argentière, Mont Blanc, France. J. Glaciol. 12, 439-451. doi: $10.1017 /$ S0022143000031853

von Raumer, J. F., Stampfli, G. M., and Bussy, F. (2003). Gondwanaderived microcontinents-the constituents of the Variscan and Alpine collisional orogens. Tectonophysics 365, 7-22. doi: 10.1016/S0040-1951(03) 00015-5
Conflict of Interest Statement: The authors declare that the research was conducted in the absence of any commercial or financial relationships that could be construed as a potential conflict of interest.

Copyright $\odot 2017$ Thomazo, Buoncristiani, Vennin, Pellenard, Cocquerez, Mugnier and Gérard. This is an open-access article distributed under the terms of the Creative Commons Attribution License (CC BY). The use, distribution or reproduction in other forums is permitted, provided the original author(s) or licensor are credited and that the original publication in this journal is cited, in accordance with accepted academic practice. No use, distribution or reproduction is permitted which does not comply with these terms. 